\title{
Financial Barriers to Primatological Field Work: a Brief Commentary
}

\section{Laura Cyra Loyola ${ }^{1}$}

Received: 27 June 2019 / Accepted: 8 July 2019 /Published online: 29 August 2019

(C) Springer Science+Business Media, LLC, part of Springer Nature 2019

"Hi, my name is Laura and I hear you are looking for free labor." Ten years after earning my bachelor's degree I contemplated returning to academia, and this is how I introduced myself to a complete stranger in New York, when I was in search of pregraduate school field experience. Several prospective academic, nonacademic, and professional mentors told me that I needed primate-related field experience before I should even consider applying to graduate school. Let me repeat that, this field work was not for my own research; I was not already enrolled in graduate school. This was "highly recommended" field work just so that I could apply to graduate school, with no guarantee of acceptance.

There are a variety of ways to gain coveted pre-graduate school field experience: an independent field school, a field school sponsored by or affiliated with a host university, postgraduate programs, or postgraduate field research assistantships. I have focused this commentary mostly on postgraduate experiences, as undergraduate student research assistantships tend to focus on laboratory work or other on-campus research.

I appreciate the advice I was given now, as I have lived the results of it: pre-graduate school field work is often the defining moment of whether someone chooses to continue on the path toward a $\mathrm{PhD}$ or not. For me, the challenges and rewards of my pre-graduate school field work experience solidified my aspirations of continuing in field research and academia, leading me to earning my $\mathrm{PhD}$ in 2015 from the University of Southern California. To gain that requisite experience I spent months saving my salary and arranged for time off of work (I quit). I then went through my savings and used credit cards to purchase field gear and plane tickets so that I could work with no pay for 6 months, which was a struggle and a compromise. Fortunately, my "roommate" paid the balance of my rent while I was gone; at 30 years old I did not have to move myself, or my belongings, in with my parents, or a storage unit, though this is not unheard of in our profession and many others when starting out.

\section{Handling Editor: Joanna M. Setchell}

Laura Cyra Loyola

loyola@usc.edu

1 Spatial Sciences Institute, Dornsife College of Letters, Arts and Sciences, University of Southern California, Los Angeles, CA 90089, USA 
I recognize that the graduate student I worked for could not pay me. I have been there myself now and did not have enough funds to bring on any novice students; I do not blame him, I blame the system. Those wonderful 6 months left me worse than broke; they left me in debt. I am not alone in this experience. After an informal survey of the audience and discussants during the Roundtable on Diversity and Inclusion in Primatology at the 2018 IPS Congress (Setchell et al. 2018), I realized that many of us did not proceed directly to our doctoral training, but rather pursued other graduate (master's) programs, or took time off to work and live. And I know that many people simply cannot afford to take the steps I took. They cannot leave their families, they are unable to earn extra money, or they cannot afford to go into more debt.

With no official data on this subject or official survey, I used Primate Info Net as the main source of data for currently available field work positions (2018). This is where the majority of positions are listed, it is well known, and many prospective students are directed to this site. I gathered additional data from a variety of field programs. After tabulation of the 29 positions that were listed as field work* (volunteer positions $(N=$ 18) are listed separately on the site and are mostly field research assistants, and are not included in this analysis), the results are as follows:

- only 1 offered a salary of $<200 \mathrm{USD} /$ month;

- 26 were not paid; and

- 2 did not specify if they were paid or not.

Of those 29 field work positions:

- 5 offered some reimbursement of expenses on completion of the time commitment;

- 7 paid for lodging;

- 4 clearly stated that participants were responsible for their own gear and medical expenses; and

- 19 explicitly reported that no expenses would be covered.

Most preferred a 12-month commitment, though a few offered 3- and 6-month terms. Most principle investigators want research assistants to work for at least a year to gain some return on the investment of training time. Reported estimated costs ranged from $50 \mathrm{USD} /$ month to $875 \mathrm{USD} / \mathrm{month}$, the exception being a position in Ethiopia with associated costs of 1200 USD/month.

Field schools* are an alternative to field work, if a student is aware of these opportunities ahead of time. Most independently run field schools operate during winter or summer breaks and not during regular semester sessions (Field Projects International 2018; Maderas Rainforest Conservancy 2018). However, even if they are offered through a university, they are not covered by regular tuition and therefore scholarships do not apply. The most affordable 2-week program tuition in 2018 was 2095 USD, not including flights, equipment, medical insurance, personal expenses, or lodging. A 4-week course through the University of Arizona was listed as 6750 USD, while the summer Rutgers Field School program was 5000 USD.

Addressing this financial barrier to inclusion is vital to keeping primatological sciences a relevant discipline. The costs incurred by prospective students to participate in pre-graduate school field experiences not only make aspiring researchers beholden to others, but it greatly limits the pool of potential researchers. I have recently seen (and 
contributed to) a fundraising solicitation via social media to support the undergraduate student of a colleague in their first ever field experience. This is not unusual. We should not rely on solicitations and donations to fund field work. It limits the diversity of our field, and the diversity of perspectives that can engage in the conversations and spark novel ideas that push everyone to be better investigators.

I am grateful to be able to share my own journey and experiences in this conversation, which began with the Roundtable on Diversity at the Joint Meeting of the International Primatology Society (IPS)/American Society of Primatologists (ASP) in 2016 (Schmitt 2016). Then, the discussants generally addressed bottlenecks and barriers to inclusion in the field of primatology, including how to seek out a mentor/how to be a good mentor, how to be safe in the field and at home institutions, and the varied economic and institutional constraints of pre-graduate school field experience. This commentary addressed the last of these issues, focusing on the economic constraints of gaining pregraduate school field experience, and though cultural norms and barriers that disproportionately impact lower-income and underrepresented minorities cannot be completely ignored in this conversation, I do not address them specifically in this commentary.

Potential solutions to this issue include, but are not limited, to professional (national and international) organizations offering support for pre-degree field experience, especially for in-country students; universities and funding agencies including funds for experiential opportunities for post-baccalaureates; or dedicated National Science Foundation-type resources for post-baccalaureate experience. Universities, university foundations, private foundations, and philanthropists must focus on investing in future scientists. They are vital in bringing diverse students with fresh and enthusiastic points of view and scientific perspectives to the table.

Let the way that I introduced myself not be the way that future primatologists introduce themselves to potential supervisors. Let this be the wake up call for this and other organizations to remove this financial barrier to entering our discipline. Let us stop making future generations of primatologists free labor before they even enter the field.

*Comments made here reflect only the financial aspect of these opportunities and do not make any claim as to the potential benefit of one over the other.

Acknowledgements I would like to thank close friends and mentors, Drs. Roberto A. Delgado and Julie A. Wieczkowski, for their valuable feedback on this commentary. I would also like to thank my family and friends who over the years "subsidized" my educational experiences and without whom I would not have made it through, or even to, graduate school.

\section{References}

Field Projects International. (2018). www.fieldprojects.org. Accessed 17 July 2018.

Maderas Rainforest Conservancy. (2018). La Suerte, Costa Rica. http://www.maderasrfc.org. Accessed 17 July 2018.

Primate Info Net. (2018). National Primate Research Center, University of Wisconsin, Madison. http://pin. primate.wisc.edu/jobs/list/avail. Accessed 16 July 18.

Schmitt, C. (2016). Roundtable on diversity. In Joint Meeting of the International Primatological society and the American Society of Primatologists. Chicago, IL: Abstract 7853.

Setchell, J. M., Covert, H. H., Loyola, L. C., Cheyne, S. M., Blair, M., et al (2018). Roundtable on diversity and inclusion in primatology. In 27th International Primatological Society Congress. Nairobi, Kenya: Abstract 8094 . 